\title{
Analysis of Microplastic Intake by Human through Red Kurisi Fish (Nemiptus Japonicas) and Mackerel (Rastrelliger Sp) Consumption in the Coastal Area Community of Tamasaju Village, North Galesong, Takalar Regency
}

\author{
Lisawati Nurtang $^{1 *}$, Anwar Daud ${ }^{1}$, Shinta Werorilangi ${ }^{2}$, Anwar Mallongi ${ }^{1}$, Erniwati Ibrahim ${ }^{1}$,
} Rachman Syah $^{3}$

${ }^{1}$ Department of Environmental Health, Faculty of Public Health, Hasanuddin University Indonesia

${ }^{2}$ Department of Marine Sciences, Faculty of Marine and Fisheries Sciences, Hasanuddin University Indonesia

${ }^{3}$ Research Institute for Brackish Water Cultivation Fisheries and Fisheries Extension

*Corresponding Author

Lisawati Nurtang

\section{Article History}

Received: 26.09.2020

Accepted: 13.10 .2020

Published: 15.10 .2020

\begin{abstract}
Plastic waste has become one of the most serious threats to the marine environment. Among the plastic waste that is of particular concern are microplastics because of their small size. The purpose of this study was to analyze the level of microplastic intake through fish consumption in the coastal area of Tamasaju Village, North Galesong, Takalar Regency. This research is a type of qualitative research with a descriptive approach. The samples in this study were 30 respondents and 20 fish with the types of mackerel and red kurisi fish. Data obtained by interview using questionnaires, identification of microplastics in fish in the laboratory, and identification of polymer types using FTIR spectroscopy. The results showed that the total number of microplastics found was 18 particles. The type of microplastic found was a line shape with different color and size variations, with the blue line dominating, namely $77.77 \%$. The average concentration of microplastics found in fish was $3.1 \mathrm{mg} / \mathrm{kg}$, with polystyrene polymer content. It is known that the average intake of non-carcinogenic microplastics by the community is $0.04 \mathrm{mg} / \mathrm{kg} / \mathrm{day}$ (non-carcinogenic) and as much as $0.02 \mathrm{mg} / \mathrm{kg}$ /day (carcinogenic). This shows that the intake of microplastics by humans through fish consumption is still categorized as safe.
\end{abstract}

Keywords: Fish, Intake analysis, Microplastics, Polystyrene.

\section{INTRODUCTION}

Plastics have penetrated everyday life, from clothing to coatings and from transportation vehicles to cleaning products. So that the losses caused by the abundance of plastic waste are very visible in the environment. Among the plastic waste that is of particular concern is microplastics because of their small size [16]. Microplastics are defined as small pieces of plastic smaller than five millimeters in size $[2,10]$.

The global release of primary microplastics into the sea is estimated at 1.5 million/year [2]. Most of the microplastics come from land which enters the marine environment, including flowing through rivers [9]. Microplastics have been found in drinking water, bottled water ranges from 0 to more than 104 particles/L with an average value of 103 particles/Lt [27].

The consumption of microplastics by fish is closely related to plastic pollution in the marine environment. Microplastics digested by fish are dominated by microplastics that are $<1 \mathrm{~mm}$ in size, are shaped like films and are transparent in color [29]. In addition, microplastic particles are found in sediments and filter feeding animals [13]

Copyright (C) 2020 The Author(s): This is an open-access article distributed under the terms of the Creative Commons Attribution 4.0 International License (CC BY-NC 4.0) which permits unrestricted use, distribution, and reproduction in any medium for non-commercial use provided the original author and source are credited. 
Plastic waste pollution in Indonesia has reached serious limits, according to Jambeck et al. [13] Indonesia ranks 2 as the country that produces the most plastic waste. Indonesia contributes $0.48-1.29$ million metric tons of plastic waste to the sea every year. Thus, in Indonesia, total plastic waste is predicted to reach 9.52 million tonnes in 2019 [14]. The identification of the presence of microplastics in the Makassar region has not found any alarming cases, including their effects on humans. However, research at TPI Paotere Makassar City by Rochman [23] showed quite high results, namely the number of particles in each fish ranged from 0-21 particles/individual.

One of the famous fish auction venues in Makassar City is the Beba North Galesong Fish Auction in Takalar Regency. Various types of seafood are traded at this auction, even visitors or buyers who come can directly enjoy the catch of fishermen which are provided in food stalls along the entrance to the Beba Fish Auction Place (TPI), Tamasaju Village, including a village that is very close to the Beba fish auction. The people in this village have the main profession as fishermen, and most of the people here use seafood as their daily side dish.

The presence of microplastics in marine species that are often consumed by the public raises concerns about the level of risk of microplastics to human health. Therefore, in this study, we will examine the evidence of seafood (fish) contamination by microplastics, and the level of risk from the presence of microplastics in the marine environment to human health.

\section{Materials ANd Methods}

The materials used in this study were samples of red kurisi fish and mackerel obtained from the Beba Fish Auction Center (PPI) (Figure 1). While the respondents are the people along the coastal area of Tamasaju Village, North Galesong, Takalar Regency (Figure 2). Other materials used in this study are $20 \% \mathrm{KOH}$ solvent and aquades.

\section{Location and research design}

This research will be conducted in May-June 2020. Fish samples were taken for 1 day at 06.00 - 07.00 WITA on June 25, 2020 at the Beba Fish Auction Center. This type of research is descriptive analysis with the Environmental Health Risk Analysis (EHRA) approach, namely research using questionnaires, interviews, laboratory examinations and calculations using the EHRA formula, to determine the level of public health risk based on risk agent concentration, intake rate, frequency of exposure, duration of exposure and weight.

\section{Population and sample}

Fish samples were taken by random sampling, namely as many as 20 fish, 10 each of red kurisi fish and 10 mackerel. Furthermore, fish samples are stored in a coolbox and taken to the laboratory for analysis.

Distribution of questionnaires and interview process to 30 people in Tamasaju Village were conducted for 2 days at 10.00 - 16.00 WITA. The location of the interview for respondents was only conducted in 4 hamlets, namely; Sawakung Hamlet, Beba Hamlet, Campagaya Hamlet, and Borong Calla Hamlet. This is because only the four hamlets are directly adjacent to the sea.

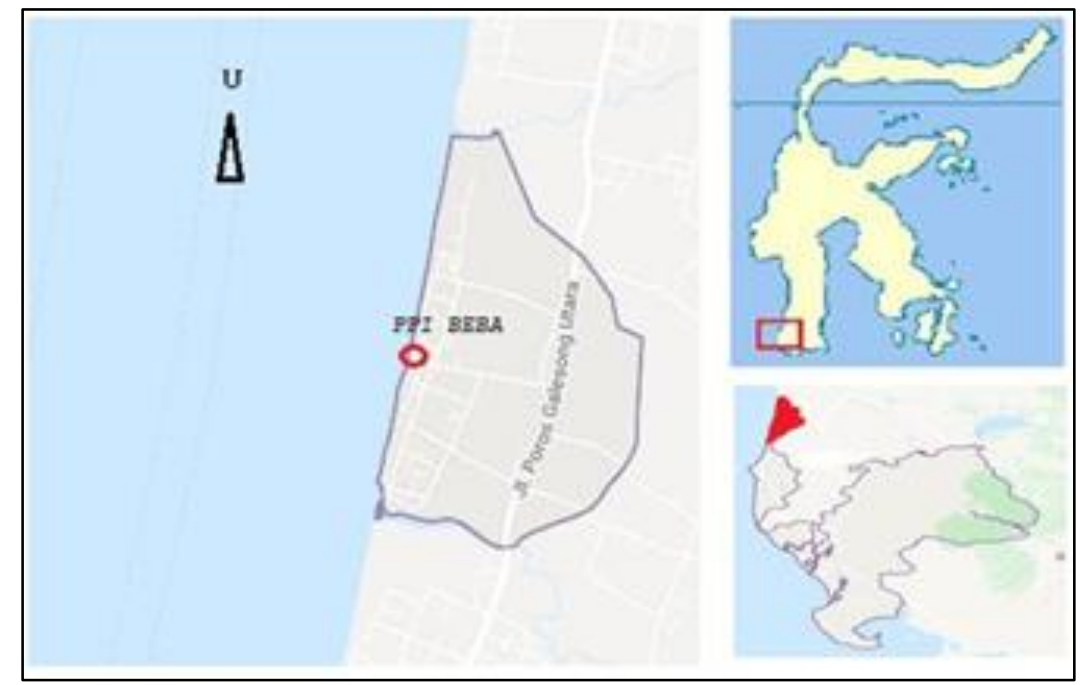

Fig-1: Fish Sampling Location 


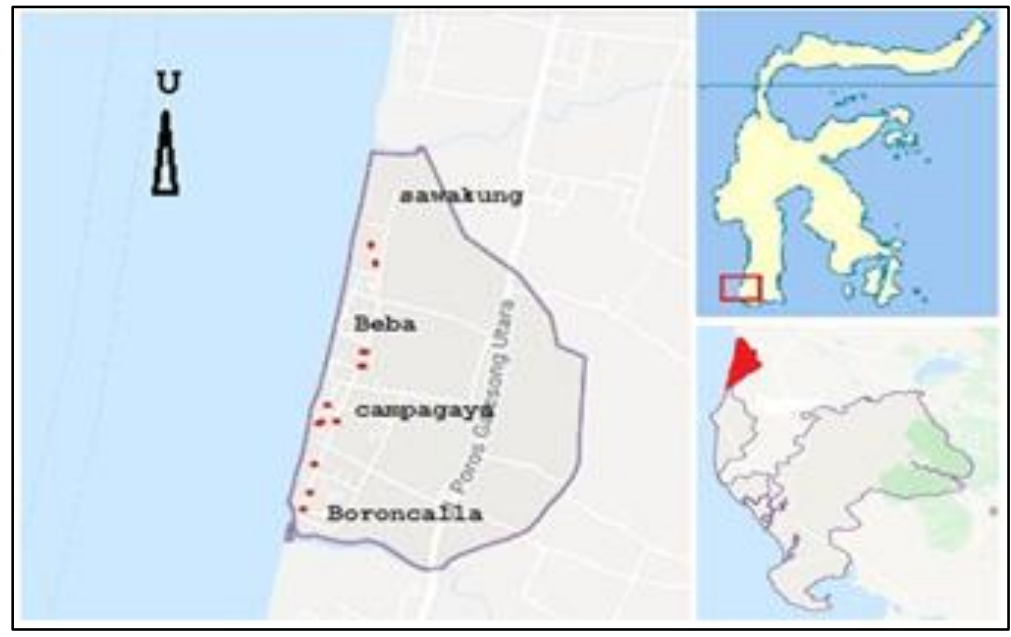

Fig-2: Feces Sampling Location

\section{Laboratory Analysis}

The microplastic analysis procedure on fish samples refers to the workings of Rochman et al. [24]. Microplastic analysis consists of several stages. These stages are sample preparation, destruction of organic matter with $\mathrm{KOH} \%$ solvent, microplastic observation with a microscope, microplastic measurement using imageJ software. The fish sample was dissected and separated from the intestine. The crushed fish intestines are then placed into the sample to extract plastic debris from the fish intestines. Each sample pot containing 10 grams of fish intestine was filled with 20\% (20-50 $\mathrm{ml}) \mathrm{KOH}$ (Potassium Hydroxide) solution up to 3 times the volume of tissue in ultrapure water and incubated for 7 days at room temperature to digest organic matter. For each sample, the digested material was carefully sorted and examined under the euromax nexius zoom trinocular microscope. To determine the length and width of each microplastic, all cuttings were photographed and measured digitally using the ImageJ software package. Furthermore, microplastic polymer analysis in fish was determined using a Fourier Transform Infrared (FTIR) Spectrophotometer (Shimadzhu, IRPrestige-21).

\section{Data Analysis}

The statistical analysis method used in this research is the descriptive statistical test. The purpose of this test is to determine the total abundance of microplastics in fish samples, to determine the average concentration of microplastics in fish, to determine differences in intake rate $(\mathrm{R})$, frequency of exposure (FE), duration of exposure (Dt), body weight (Wb) and to determine the amount of non-carcinogenic and carcinogenic intake for each respondent. This descriptive test was carried out using Microsoft Office Excel 2010 software.

\section{RESULTS}

\section{Microplastic Identification in Fish}

The fish found based on the respondent's consumption map were red kurisi fish (Nemiptus japonicas) and mackerel (Rastrelliger sp.) As shown in Table 1. Red fish is the demersal fish species most frequently consumed by almost all coastal fishing families in Tamasaju village. Meanwhile, mackerel is a type of pelagic fish which is also the favorite fish of the coastal residents of Tamasaju, besides because the price is very cheap it is also because the texture of this fish meat is very tasty after being processed.

Table -1: Identified Fish Species Containing Microplastics

\begin{tabular}{|l|l|c|}
\hline \multicolumn{1}{|c|}{ Species Name } & Identification of Fish Species in Reference & The Type of Fish Found \\
\hline $\begin{array}{l}\text { Demersal fish: Red kurisi } \\
\text { fish (Nemiptus japonicas) }\end{array}$ & Source: (Bleeker, 1851) & \\
& & \\
\hline
\end{tabular}




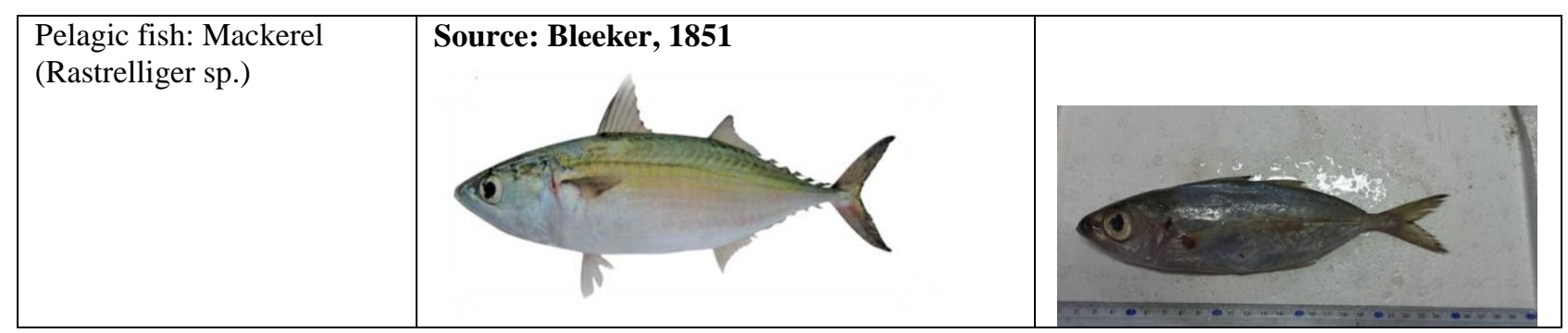

\section{Abundance of Microplastics in Fish} colors.

Generally, the types of microplastics found are line microplastics consisting of blue, mix, purple, and green

Table-2: Proportion of Microlastic Found in Fish Based on Shape and Color

\begin{tabular}{|c|c|c|c|}
\hline Shape & Color & Total & \% \\
\hline Line & Blue & 14 & $77.77 \%$ \\
\hline & Mix & 2 & $11.11 \%$ \\
\hline & Purple & 1 & $5.50 \%$ \\
\hline & Green & 1 & $5.50 \%$ \\
\hline Total Particles & & 18 & $100 \%$ \\
\hline
\end{tabular}

Table 2 shows the form of microplastics found in fish bodies, generally in the form of lines or fibers. While the number of the most dominant colors is blue as much as $77.77 \%$.

The following is an image of the microplastic form found in mackerel using 45 times magnification:

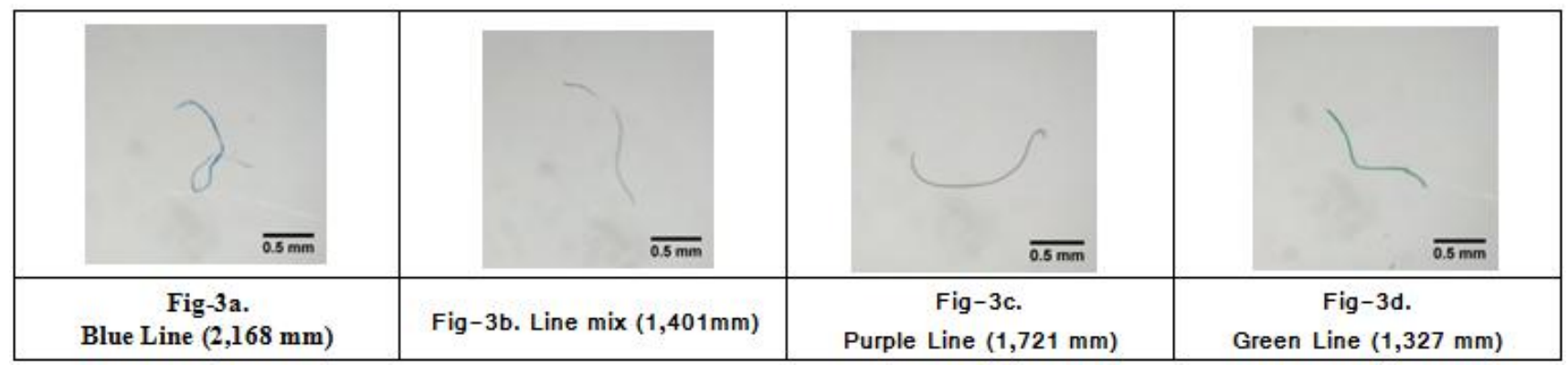

Identification of polymer types in microplastics using Spectrophotometer FTIR analysis

The results of the functional group identification when linked to the polymer, it is possible that the sample contains Polystyrene (PS) polymer.

\section{Respondent Characteristics}

Table-3: Distribution of Respondents by Gender

\begin{tabular}{|c|c|c|}
\hline Gender & Frequency & Percentage (\%) \\
\hline Male & 25 & $83,33 \%$ \\
\hline Female & 5 & $16,66 \%$ \\
\hline Total (n) & 30 & $100 \%$ \\
\hline
\end{tabular}

Table 3 shows that the respondents were dominated by men, namely $83.33 \%$, while the number of women was only $16.66 \%$.

Table-4: Distribution of Respondents by Age Group

\begin{tabular}{|c|c|c|}
\hline Age Group & Frequency & Percentage (\%) \\
\hline $20-29$ & 2 & $6,66 \%$ \\
\hline $30-39$ & 8 & $26,66 \%$ \\
\hline $40-49$ & 12 & $40 \%$ \\
\hline $50-59$ & 6 & $20 \%$ \\
\hline$\geq 60$ & 2 & $6,66 \%$ \\
\hline Total (n) & 30 & $100 \%$ \\
\hline
\end{tabular}


Table 4 shows the mean \pm SD age of the respondents, namely $43 \pm 9.84$.

Table-5: Distribution of Respondents by Body Weight

\begin{tabular}{|c|c|c|}
\hline Weight Group (kg) & Frequency & Percentage (\%) \\
\hline $36-45$ & 4 & $13,33 \%$ \\
\hline $46-55$ & 6 & $20 \%$ \\
\hline $56-65$ & 16 & $53,33 \%$ \\
\hline $66-75$ & 3 & $10 \%$ \\
\hline $76-85$ & 1 & $3,3 \%$ \\
\hline Total (n) & 30 & $100 \%$ \\
\hline
\end{tabular}

Table 5 shows the mean \pm SD of the respondent's body weight, namely $58.56 \pm 9.76$.

Concentration, Intake Rate, Frequency of Exposure, Duration of Microplastic Exposure

Table-6: Analysis Results of Microplastic Intake Indicators

\begin{tabular}{|l|r|r|c|}
\hline \multicolumn{1}{|c|}{ Intake Indicator } & Minimum & Maximum & Average \pm SD \\
\hline Concentration (mg/kg) & 1 & 10 & $3,1 \pm 1,9$ \\
\hline Intake Rate (kg/day) & 40 & 320 & $154,667 \pm 67,657$ \\
\hline Frequency of Exposure (day/year) & 104 & 260 & $190,666 \pm 43,897$ \\
\hline Duration of Exposure (year) & 10 & 60 & $38,833 \pm 14,844$ \\
\hline
\end{tabular}

Table 6 shows the results of the calculation of concentration, intake rate, frequency of exposure, and duration of microplastic exposure for 30 respondents.

\section{Daily Intake of Microplastics}

Table-7: Results of Daily Intake of Microplastic Analysis

\begin{tabular}{|l|l|l|l|}
\hline Daily Intake (mg/kg/day) & Minimum & Maximum & Average \pm SD \\
\hline Intake non carcinogenic & 0,0095 & 0,093 & $0,047 \pm 0,025$ \\
\hline Intake carcinogenic & 0,0040 & 0,039 & $0,020 \pm 0,0019$ \\
\hline
\end{tabular}

Table 7 shows the results of the analysis of daily intake (intake) of 30 respondents.

\section{DISCUSSION}

\section{Microplastic Line Shape}

Line is a form of microplastic resembling a rope. The way to distinguish it from other particles in the sample solution is to distinguish it in shape and color. Microplastics in the form of fiber or line have the characteristics of a slightly cylindrical, fibrous, striking color and elastic shape when pressed with pins or tweezers.

The lines found in fish bodies generally come from the degradation of fishing nets and tarpaulin covers used by fishermen. This is according to what is expressed in research [28]. That the line is generally sourced from high human activity in the sea. Line is also thought to have originated from leftover threads, because along the Beba beach, Tamasaju Village, there are many seats covered with cloth that are placed on the shoreline. This statement is expressed in the research of Lo et al. [18].

\section{Abundance of Microplastics}

The microplastics found in fish samples on Beba beach, Tamasaju Village, indicate the occurrence of plastic waste pollution around the sea in the coastal area of Tamasaju Village. Based on the survey results, it is evident that residents of the Tamasaju coastal area throw plastic waste into the sea, especially fish auction activities at PPI Beba. These plastics are carried by currents into the middle of the sea and degraded by sunlight so that they are destroyed into plastic debris which is then consumed by marine biota. This is in accordance with the statement of Daud, A [4] that aquatic organisms can be contaminated by microplastics either through loaded water or food from other organisms containing microplastics. In addition, fish can become contaminated after being caught through storage and transportation in fragile plastic containers.

\section{Polystyrene (PS)}

Polystyrene is a polymer with the monomer styrene. Pure solid polystyrene is a colorless, hard plastic with limited flexibility. Polystyrene is widely used in household products such as brooms, combs, basins, clothes hangers, 
buckets, and bristles. Based on this statement, it is suspected that this polymer was found in microplastics which came from the degradation of plastic waste dumped by the community into the sea, so that the debris from the plastic waste was swallowed up by the fish.

Various polymers are synthesized and used for domestic and industrial purposes. Different polymers have different densities [22]. PE, PP, PS, and PES are the main types of polymers in coastal and subtidal sediments. Polystyrene (PS) has been found to be more common along the coasts of South Korea and Uruguay [19]. PS beads embedded in PS products can easily release through weathering and are usually in the size range (1-5 mm) [11]. Each type of polymer exhibits environmental behavior including the interaction of biota with chemicals in the vicinity.

\section{Microplastics through Seafood}

Microplastics have spread in marine environments and have been shown to be found in fish guts. Microplastics have been found in wild and agricultural mollusks, such as blue clams (Mytilis edulis), Pacific oysters (Crassostrea gigas) all of which are filter feeders [25]. In contrast to fish, where microplastics are mostly found in the digestive tract, while in shellfish, microplastics can spread to every tissue of the shells [21]. An analysis of four fish species purchased from a local market in Malaysia concluded that people can consume up to 246 man-made particles (microplastics and pigments) per year [1].

In humans, most of the microplastic consumption of seafood is likely to come from species eaten as a whole, such as shellfish, oysters, shrimp, crab, and some small fish. However, exposure of microplastics to humans is not limited to the consumption of the species mentioned above, but it is possible that other seafood, such as fish muscle tissue, can become contaminated either in organisms or during processing activities.

\section{Impact on Human Health}

Microplastics can enter the human body via two main routes: air through the nose to the lungs and ingestion through the mouth into the stomach. Ingesting microplastics through food consumption increases health problems due to the potential for translocation of particles from the digestive tract to other organs or tissues and as a mechanism for the delivery of toxic chemicals. Plastics come in various forms, each of which has different effects when it accumulates in the human body depending on the chemicals contained in the microplastic. The potential for chemical toxicity in microplastics is based on manufacturing, adsorption properties, and absorption properties in the human body [10].

Further clues regarding the effects of microplastics entering the human body can be found in the medical literature. Once in the human body, micropastics are thought to cause non-carcinogenic and carcinogenic effects when microplastics have passed the threshold of quality that should enter the body.

Another health problem has to do with bacteria that grow on microplastics. One study looked at bacteria that live on the surface of microplastics that are collected in the northern and Baltic seas [15]. This study found vibrio parahaemolyticus bacteria on the surface of polyethylene, polypropylene, and polystyrene fragments. Bacteria can cause digestive disease in humans, and more research is needed to understand whether pathogens on the surface of microplastics consumed by humans pose a serious risk of disease.

\section{CONCLUSiONS}

The microplastics found in red kurisi fish (Nemiptus japonicas) were 11 particles, and mackerel (Rastrelliger sp.) Was 7 particles. The microplastics found were only lines with blue lines dominating the other colors, namely $77.77 \%$. The microplastics in this line shape are thought to have originated from the degradation of fishing nets, tarp covering the fishing boats, and the lining of the seats along the shoreline of Beba, Tamasaju Village. Data analysis of daily intake showed that the mean $\pm \mathrm{SD}$ of non-carcinogenic intake was $0.047 \pm 0.025 \mathrm{mg} / \mathrm{kg} / \mathrm{day}$ and the mean $\pm \mathrm{SD}$ of carcinogenic intake was $0.020 \pm 0.0019 \mathrm{mg} / \mathrm{kg} /$ day.

\section{ACKNOWLEDGMENT}

Thank you to the Laboratory of Aquatic Productivity and Fertility, Faculty of Marine and Fisheries Sciences, Hasanuddin University for providing laboratory facilities and to the people of Tamasaju Village who are willing to become respondents in this study so that this research can run well and smoothly.

\section{REFERENCES}

1. Karami, A., Golieskardi, A., Ho, Y. B., Larat, V., \& Salamatinia, B. (2017). Microplastics in eviscerated flesh and excised organs of dried fish. Scientific reports, 7(1), 1-9. 
2. Boucher, J., \& Friot, D. (2017). A Global Evaluation of Sources Primary Microplastics in the Oceans: A Global Evaluation of Sources.

3. Bailly, N. (2010). Rastrelliger brachysoma/Short Mackerel (Bleeker, 1851). www.fishbase.org.

4. Chandra M, Sitompul., Iskandar HS., Tomo K., Synthesa P., Sondakh, Gitrix M.

5. Daud, A., Ishak, H. (2019). Kesehatan Lngkungan Kontemporer. Gosyen Publishing. Yogyakarta: 098/DIY/2017. xvi, 513 halaman.

6. Direktorat Jendral PP dan PL Kementeriann Kesehatan. (2012). Pedoman Analisis Risiko Kesehatan Ligkungan (ARKL): Bakti Husada, Hal 1-82

7. FAO. (2001). Species Identification Guide: The Living Marine Resources of The Western Pacific. Food and Agriculture Organization, Rome, 6:3737-3739.

8. FAO. (1995). Food Standards Programme. Joint FAO/WHO Expert Consultation On The Application Of Risk Analysis To Food Standards Issues. Recommendations to the Codex Alimentarius Commission. ALINORM 95/9, p. 15 .

9. Frose, R., \& Pauly, E.D. (2020). Fishbase Decapterus Macrosoma. Accessed through: world Resgister of marine species: http://www.marinespecies.org/alphia.php? $p=$ taxdetails\&id=218426

10. Gabriel, L. (2018). Marine Microplastic Debris: An Emerging Issue for Food Security, Food Safety and Human Health Marine Pollution Bulletin, 133(1): 336-48.

11. GESAMP. (2019). Guidelines For the Monitoring \& Assessment of Plastic Litter in the Ocean Reports \& Studies 99

12. Graca, B., Szewc, K., Zakrzewska, D., Dolega, A., \& Szczerbowska, B.M.. (2017). Sources and Fate of Microplastics in Marine and Beach Sediments of the Southern Baltic Sea a Preliminary Study. Environ. Sci.Pollut.Res, 24:7650 -7661.

13. Jambeck, J.R., Geyer, R., Wileox, C., Siegler, T.R., Perryman, M., Andrady, A., \& Lavender, Law, K. (2015). Plastic Waste Inputs From Land Into The Ocean. (1):1655-1734. https://doi.org/10.1017/ CBO9781107415386.010.

14. Jahan, S. (2019). Interrelationship of Microplastic Pollution in Sediments and Oysters in a Seaport Environment of the Eastern Coast of Australia Science of the Total Environment 695:133924. https://doi.org/10.1016/j.scitotenv.2019.133924.

15. KLHK. (2018). Kementrian Lingkungan Hidup dan Kehutanan. Retrieved January 4, from www.menlhk.go.id.

16. Kristein. (2016). Dangerous hitchhikers? Evidence for Potentially Pathogenic vibrio spp. on Microplastic Particles. Marine Environ Res, 1:1-8 . https://www.ncbi. Nlm.nih.gov/pbmed/27411093.

17. Liu, Kai. (2019). Accurate Quantification and Transport Estimation of Suspended Atmospheric Microplastics in Megacities : Implications for Human Health. Environment International, 132(8):105-127. https://doi.org/10.1016/j.envint.2019.105127.

18. Lusher, A.L., Peter, H., \& Jeremy, M. (2017). Microplastics in Fisheries and Aquaculture. Roma: Food and Agriclture Organization (FAO) of The United Nations.

19. Lo H.S., Xu X., Wong C.Y., \& Cheung S.G. (2018). Comparisons of Microplastic Pollution Between Mudflats and Sandy Beaches in Hong Kong. Environment Pollution, 236:208-217. https://doi.org/10.1016/j.envpol.2018.01.031

20. Lozoya J.P., de Mello F., Carrizo D., Weinstein F., Olivera Y., Cedres F., Pereira M. \& Fossati M. (2016). Plastics and Mikroplastics on Recreational Beaches in Punta del Este (Uruguay): Unseen Critical Residents? Environ.Polunt, 218:931-941.

21. Lu, L. (2019). Interaction between Microplastics and Microorganism as Well as Gut Microbiota: A Consideration on Environmental Animal and Human Health. Science of the Total Environmen,t 667: 94-100. https://doi.org/10.1016/j.scitotenv.2019.02.380.

22. Prabhu, K. (2017). Adherence of Microplastics to Soft Tissue of Mussels: A Novel Way to Uptake Microplastics Beyond Ingestion. Sci. of The Total Environ, 635: 635-40 https://doi.org/10.1016/j.scitotenv.2017.08.053.

23. Rani, M., Shim, W.J., Han, G.M., Jang, M., Song, Y.K., Hong, S.H. (2017). Benzotriazole Type Ultraviolet Stabilizers and Antioxidants in Plastic Marine Debris and Their New Product. Sci Total Environ, 579:745-754.

24. Rochman, Chelsea, M. (2015). Anthropogenic Debris in Seafood: Plastic Debris and Fibers from Textiles in Fish and Bivalves Sold for Human Consumption. Nature Publishing Group (8):1-10.

25. USEPA. (2000). Supplementary Guidance For Conducting Health Risk Assessment of Chemical Mixtures. EPA/630/R-00/002, Aug 2000. http://cfpub.epa.gov/ncea/cfm/recordisplay.cfm?deid=20533.

26. Tortora, G.J., Anagnostakos, N.P. (1987). Prinsip Anatomi dan Fisiologi (Fifth ed.). New York: Harper \& Row. hal.624. ISBN 978-0-06-350729-6 .

27. WHO. (2019). Microplastics in Drinking Water. Sumber: http://apps.who.int/iris.

28. Zhao, J., Ran, W., Teng, J., Liu, Y., Liu, H., Yin, X., Cao, R., Wang, Q. (2018). Microplastic Pollution in Sediments from the Bohai Sea and the Yellow Sea, China. Sci. Total Environ, 640-641. https://doi.org/10.1016/j.scitotenv.2018.05.346

29. Zhu, L. (2019). Microplastic Ingestion in Deep-Sea Fish from the South China Sea. Science of the Total Environment, 677: 493-501. https://doi.org/10.1016/j.scitotenv.2019.04.380. 